\title{
Liver transplant versus non-liver transplant patients underwent appendectomy with presumed diagnosis of acute appendicitis: Case-control study
}

\author{
Kemal Barış Sarıcı, M.D., (1) Sami Akbulut, M.D., (ㄷ) Cemalettin Koç, M.D., \\ 당 Adem Tuncer, M.D., 고 Sezai Yılmaz, M.D.
}

Department of Surgery and Liver Transplant Institute and, İnönü University Faculty of Medicine, Malatya-Turkey

\begin{abstract}
BACKGROUND: This study aims to compare liver transplant and non-liver transplant patients who underwent appendectomy with a presumed diagnosis of acute appendicitis.

METHODS: Demographic and clinicopathological features of 13 liver transplant recipients (transplant group) who underwent posttransplant appendectomy with a presumed diagnosis of acute appendicitis were compared with the features of 52 non-liver transplant patients (non-transplant group). They underwent appendectomy with a presumed diagnosis of acute appendicitis during the same time period. The transplant group was matched at random in a I: 4 ratio with the non- transplant group. While the continuous variables were compared using the Mann Whitney-U test, categorical variables were compared with Fisher's exact test. A p-value of less than 0.05 was considered statistically significant.
\end{abstract}

RESULTS: A total of 65 patients aged between one year and 84 years were included in this study. While the age of the 52 patients ( 32 male and 20 female) in the non- transplant group ranged from 17 years to 84 years, the age of the 13 patients (nine male and four female) in the transplant group ranged from one year to 64 years. Statistically significant differences were noted between both groups concerning WBC $(p=0.002)$, neutrophil $(p=0.002)$, lymphocyte $(p=0.032)$, platelets $(p=0.032), \operatorname{RDW}(p=0.00 \mathrm{I}), C R P(p=0.009), P N R$ $(p=0.042), W N R(p=0.03)$, and appendiceal length $(p<0.001)$. The negative appendectomy rate was relatively higher in transplant than the non-transplant group but this difference was not statistically significant (30.8\% vs. $21.2 \%$; $p=0.477)$. Perforated acute appendicitis occurred more frequently in the transplant group; however, this difference was not statistically significant $(30.8 \% \mathrm{vs}$. 9.6\%; $\mathrm{p}=0.070)$.

CONCLUSION: WBC and neutrophil were lower in the LT group; however, the CRP and RDW were higher in the LT group. Further, perforation and negative appendectomy rates were higher in the LT group, although this difference was not statistically significant.

Keywords: Liver recipients; acute appendicitis; Liver transplantation; negative appendectomy; perforated appendicitis.

\section{INTRODUCTION}

Acute appendicitis (AAP) is one of the most common causes of admission to emergency units, and appendectomy is one of the most frequently performed surgical procedures in the world. ${ }^{[1]}$ The lifetime risk of an AAp episode is $8.6 \%$ in male and $6.7 \%$ in female patients. ${ }^{[1-5]}$ Epidemiologic studies state that the risk of undergoing an appendectomy at any point in their lives in male and female patients is $12 \%$ and $23 \%$, respectively. ${ }^{[1]}$ Parameters, such as leukocyte count, neutrophil count, C-reactive protein (CRP) level, some interleukins (IL), procalcitonin level, and the findings of physical examination, used in the diagnosis of AAp depend on the extent of the host response to the inflammation in the body. Despite the contradicting findings in the literature, there is a general consensus that AAp signs and symptoms in an immunocompromised individual may differ from AAp signs and symptoms in an immunocompetent patient. ${ }^{[6-8]}$ Thus, it has been sug-

Cite this article as: Sarıcı KB, Akbulut S, Koç C, Tuncer A, Yılmaz S. Liver transplant versus non-liver transplant patients underwent appendectomy with presumed diagnosis of acute appendicitis: Case-control study. Ulus Travma Acil Cerrahi Derg 2020;26:705-712.

Address for correspondence: Sami Akbulut, M.D.

İnönü Üniversitesi Tıp Fakültesi, Karaciğer Nakli Enstitüsü ve Genel Cerrahi Anabilim Dalı, Malatya, Turkey

Tel: +90 422 - 34l 0660 E-mail: akbulutsami@gmail.com

Ulus Travma Acil Cerrahi Derg 2020;26(5):705-7I2 DOI: 10.14744/tjtes.2020.52368 Submitted: 06.01.2020 Accepted: 14.02.2020 Online: 09.09.2020

Copyright 2020 Turkish Association of Trauma and Emergency Surgery 
gested that transplant patients may have a higher rate of late diagnosis and risk of fatal complications, such as perforation and abscess formation, due to immunosuppressive therapy received in the postoperative period. ${ }^{[7]}$ The present study aims to compare the demographic and clinicopathologic data of the immunosuppressed liver transplant (LT) recipients who underwent an appendectomy due to AAp to that of their non-transplant counterparts who underwent appendectomy during the same period. This study will provide an indirect means of investigation of the effects of immunosuppressive therapy on the signs and symptoms of inflammation in AAp.

\section{MATERIALS AND METHODS}

Between March 2002 and October 2019, a total of 2442 patients underwent LT in Inonu University Liver Transplant Institute, and I $3(0.53 \%)$ of these patients underwent appendectomy with a presumed diagnosis of AAp after LT. This group was defined as the LT group $(n=13)$. A control group was created for comparison with the transplant group, and this group was defined as the non-LT group $(n=52)$. The non-LT group comprised patients who presented to our emergency unit with abdominal pain in the same time period and underwent appendectomy with the presumed diagnosis of AAp. Patients with a history of corticosteroid, chemotherapeutic agent, or other immunosuppressive drug use for any reason were not included in the non-LT group. The LT group was matched at random in a $1: 4$ ratio with the non-transplant group (G*Power 3.1.9.2 software; effect size=0.7, two-tailed, power: $81.8 \%$, Df:63, critical $t=1.349$, non-centrality parameter $=2.257$ ). To minimize the bias risk, the non-LT group (control group) was enrolled by a surgeon who was not related to this study. Both groups were compared concerning age (years), sex (male, female), white blood cell (WBC) count, neutrophil count, lymphocyte count, platelets, red cell distribution width (RDW), platelet distribution width (PDW), mean corpuscular hemoglobin (MCH), mean platelet volume (MPV), mean corpuscular volume (MCV), bilirubin level, CRP level, white cell neutrophil ratio (WNR), white cell lymphocyte ratio (WLR), neutrophil to lymphocyte ratio (NLR), platelet to lymphocyte ratio (PLR), platelet to the neutrophil ratio (PNR), appendix diameter $(\mathrm{mm})$, appendix length $(\mathrm{mm})$, presence of acute appendicitis, ultrasonographic findings, and histopathological findings.

\section{Immunosuppression for LT Recipients}

Intravenous methylprednisolone was administered immediately after the completion of the hepatic artery anastomosis during liver graft implantation. Thereafter, peroral steroid treatment was initiated on a postoperative day one and tapered from $100 \mathrm{mg} /$ day to $0.25 \mathrm{mg} / \mathrm{kg} /$ day and stopped 3-6 months after surgery, except in patients with autoimmune diseases. Cyclosporine was only prescribed in pediatric patients who underwent LT due to acute liver failure or neurological Wilson's disease. Mycophenolate mofetil and tacrolimus were usually initiated on postoperative day 3 . Tacrolimus was the first choice for immunosuppressive therapy in most cases except in patients with renal dysfunction or hepatorenal syndrome. In patients with impaired or deteriorated renal function, tacrolimus was stopped or tapered and everolimus was added until renal function improved.

\section{Statistical Analysis}

The statistical analyses were performed using IBM SPSS Statistics v25.0 (Statistical Package for the Social Sciences, Inc, Chicago, IL, USA). The quantitative variables were expressed as, median and min-max. The qualitative variables were reported as number and percentage (\%). Kolmogorov-Smirnov test was used to determine whether the quantitative variables showed normal distribution. Mann Whitney-U test was used to compare the quantitative variables. Fisher's exact tests were used to compare qualitative variables because the minimum expected count was less than 5 for all compared parameters. A p-value of less than 0.05 was considered statistically significant. Patient medical records were retrospectively reviewed after obtaining approval from Inonu University institutional review board for non-interventional studies (Approval No: 2019/16-38I).

\section{RESULTS}

A total of 65 patients ( 41 male and 24 female) aged between one year and 84 years were included in this case-control study. While the age of the 52 patients ( 32 male and 20 female) in the non- transplant group ranged from 17 years to 84 years, the age of the 13 patients (nine male and four female) in the LT group ranged from one year to 64 years. Patients in the LT group underwent appendectomy with a preliminary diagnosis of AAp a median 339 days (min-max: 20-2023 days) after LT. While living donor LT was performed in 10 patients in the LT group, deceased donor LT was performed in the remaining three patients. Eleven of the patients in the LT group were adults, and the remaining two were in the pediatric age group (one and eight years).

There was no statistically significant difference between the groups concerning age $(p=0.163)$, sex $(p=0.753)$, PDW $(p=0.700), M C H(p=0.115), M P V(p=0.6 I I), M C V(p=0.08 I)$, TBil $(p=0.528), \quad N L R \quad(p=0.228), \quad$ PLR $(p=0.682), \quad W L R$ $(p=0.4 \mid 2)$, diameter of appendix $(p=0.7 \mid 7)$, presence of acute appendicitis according to histopathological findings $(p=0.477)$, ultrasonographic findings $(p=0.139)$, and detailed histopathological findings $(p=0.064)$. However, statistically significant difference was noted between the groups with respect to WBC count $(p=0.002)$, neutrophil count $(p=0.002)$, lymphocyte count $(p=0.032)$, platelet count $(p=0.032), \operatorname{RDW}(p=0.00 \mathrm{I})$, CRP level $(p=0.009)$, PNR $(p=0.042), W N R(p=0.03)$, and appendix length $(p<0.00 I)$.

The negative appendectomy rate was relatively higher in the LT group than in the non-LT group, but this difference was not statistically significant $(30.8 \%$ vs. $21.2 \%$; $p=0.477)$. Similar- 
ly, the clinical and histopathologically-proven perforated AAp rate was higher in the LT group than in the non-LT group; however, this difference also was not statistically significant (30.8\% vs. $9.6 \% ; p=0.070)$. There was no significant difference between the two groups in terms of postoperative wound infection, wound dissociation, intra-abdominal abscess, and adjacent organ injury. In both groups, the subcutaneous collection was treated with simple drainage in only one patient.

Table I. Comparison of the LT and No-LT appendectomy groups in terms of continuous variables

\begin{tabular}{|c|c|c|c|}
\hline Patients' characteristics & LT Group $(n=13)$ & No-LT Group $(n=52)$ & $\mathbf{p}$ \\
\hline Age, median (min-max) & $42(1-67)$ & $30(17-84)$ & 0.163 \\
\hline WBC, median (min-max) & $7.5(2.5-25)$ & $12.5(6.2-27)$ & 0.002 \\
\hline Neutrophil, median (min-max) & $5.2(2-20.7)$ & $10.2(3.9-22.3)$ & 0.002 \\
\hline Lymphocyte, median (min-max) & $1.3(0.4-1.9)$ & $1.8(0.2-5.6)$ & 0.032 \\
\hline Platelets, median (min-max) & $147(76-503)$ & $237(53-443)$ & 0.032 \\
\hline RDW, median (min-max) & $14.7(\mid 2.8-17.6)$ & $13.1(11.5-18)$ & 0.001 \\
\hline PDW, median (min-max) & |4.8 (9-18.8) & $14.8(8.7-17.6)$ & 0.700 \\
\hline $\mathrm{MCH}$, median $(\min -\max )$ & $27(17.9-32.9)$ & $29(\mid 9.6-31.5)$ & 0.115 \\
\hline MPV, median (min-max) & $9.4(6.8-11.5)$ & $9.2(5.4-11.9)$ & 0.611 \\
\hline MCV, median (min-max) & $82.5(62.6-99.5)$ & $85.4(68.4-94.2$ & 0.081 \\
\hline TBil, median (min-max) & $\mathrm{I}(0.2-2.3)$ & $0.8(0.2-3.7)$ & 0.528 \\
\hline CRP, median (min-max) & $6.1(0.3-20.7)$ & $0.8(0.1-16.7)$ & 0.009 \\
\hline NLR, median (min-max) & $5(2.3-12.4)$ & $5.4(1.4-29.5)$ & 0.228 \\
\hline PLR, median (min-max) & $169(49-429)$ & $139(29-1020)$ & 0.682 \\
\hline PNR, median (min-max) & $32(14.5-58.1)$ & $22.4(8.5-95.6)$ & 0.042 \\
\hline WLR, median (min-max) & $6.3(4-13.9)$ & $6.7(2.8-31)$ & 0.412 \\
\hline WNR, median (min-max) & I.4 (I.I-I.7) & $1.2(0.7-2.3)$ & 0.030 \\
\hline Appendix length (mm), median (min-max) & $47(30-80)$ & $70(45-110)$ & $<0.001$ \\
\hline Appendix diameter (mm), median (min-max) & $8(5-40)$ & $10(5-30)$ & 0.717 \\
\hline
\end{tabular}

LT: Liver transplantation; WBC: White blood cell; RDW: Red cell distribution width; PDW: Platelet distribution width; MCH: Mean corpuscular hemoglobin; MPV: Mean platelet volume; MCV: Mean corpuscular volume; CRP: C-reactive protein; NLR: Neutrophil to lymphocyte ratio; PLR: Platelet to lymphocyte ratio; PNR: Platelet to neutrophil ratio; WLR: White cell lymphocyte ratio; WNR: White cell neutrophil ratio; Min: Minimum; Max: Maximum.

Table 2. Comparison of the LT and No-LT appendectomy groups concerning categorical variables

\begin{tabular}{|c|c|c|c|c|}
\hline Patients' characteristics & & LT Group $(n=13)$ & No-LT Group $(n=52)$ & $\mathbf{p}$ \\
\hline \multirow[t]{2}{*}{ Sex } & Male & $9(69.2)$ & $32(6 \mid .5)$ & 0.753 \\
\hline & Female & $4(30.8)$ & $20(38.5)$ & \\
\hline \multirow[t]{2}{*}{ AAp } & Yes & $9(69.2)$ & $41(78.8)$ & 0.477 \\
\hline & No & $4(30.8)$ & II (2I.2) & \\
\hline \multirow[t]{2}{*}{ Perforation } & Yes & $4(30.8)$ & $5(9.6)$ & 0.070 \\
\hline & No & $9(69.2)$ & $47(90.4)$ & \\
\hline \multirow[t]{2}{*}{ Ultrasonographic findings } & AAp (+) & $3(33.3)$ & $32(64.0)$ & 0.139 \\
\hline & AAp (-) & $6(66.7)$ & $18(36.0)$ & \\
\hline \multirow[t]{5}{*}{ Histopathological findings } & AAp & $5(38.5)$ & $36(69.2)$ & 0.064 \\
\hline & AAp (perforated) & $4(30.8)$ & $5(9.60)$ & \\
\hline & Appendix vermiformis & $0(0.00)$ & $5(9.60)$ & \\
\hline & Fibrous obliteration & I (7.70) & $2(3.80)$ & \\
\hline & Lymphoid hyperplasia & $3(23.1)$ & $4(7.70)$ & \\
\hline
\end{tabular}


Comparison of the LT and No-LT appendectomy groups in terms of continuous and categorical variables were summarized in Table I and Table 2.

\section{DISCUSSION}

AAp is the most common disease requiring emergency surgical therapy worldwide and its current global incidence is 100 I5I per 100.000 population. ${ }^{[9,10]}$ Conversely, its incidence following solid organ transplantation is low compared to that in the normal population. However, as the frequency of solid organ transplantation is increasing with enhanced survival due to recent advancements in immunosuppressive therapy, the incidence of AAp in this subgroup of patients is increasing. ${ }^{[5,8,9,11]}$ The first publication regarding AAp in patients with LT was published in 2005 by Abt et al., ${ }^{[1]}$ and since then, 14 articles have been published with one being a review article. [2-16] Our literature review with 33 LT patients who received appendectomy for AAp has been summarized in Table 3. The studies in the field show that AAp incidence in patients with LT ranges between $0.09 \%-0.67 \% . .^{[4,6,8,9,11,15]}$ De'Angelis et al..$^{[5]}$ found that AAp developed in $0.29 \%$ of the transplant patients and $38.9 \%$ of them had undergone an LT. In our opinion, the term incidence used for documenting AAp occurrence following solid organ transplantation is inappropriate, considering its low rate of occurrence. In fact, we believe "prevalence" is a better term to define the frequency of this disease in transplant patients.

It has been suggested by many researchers that the classical signs and symptoms of AAp, such as right lower quadrant pain, loss of appetite, nausea and vomiting, and fever, are not observed in transplant patients due to the suppressive effects of immunosuppressive therapy, which in turn delay the diagnosis and increase the complication rates observed. On the contrary, some researchers state that in this subgroup of patients, the signs and symptoms of the disease are not different; rather, the severity of the symptoms may be altered. ${ }^{[4,6-8]}$ It has been suggested that combined immunosuppressive therapy used, especially in the early post-transplant period, could mask the symptoms of AAp by suppressing the inflammatory response and result in atypical manifestations of the disease. ${ }^{[7]}$ Furthermore, graft-related complications encountered in the early post-transplant period could also mask the clinical manifestations of the AAp. ${ }^{\left[{ }^{[]}\right.}$

As a result of the literature analysis we performed, fever-related data of 21 patients were retrieved, and $66.7 \%$ of these patients developed a fever during AAp episodes. In our case-control study, we found that $23.7 \%$ of the patients with LT had a fever during the development of AAp. In the literature, the interval between $L T$ and development of AAp was reported to be $8-5430$ days, and in $24.2 \%$ of the patients, AAp developed in the first 15 days following LT. Our case-control study showed that in $7.7 \%$ of the patients, AAp developed in the first postoperative month. Thus, based on our results, we disagree with the idea of the other researchers $^{[7]}$ proposing that AAp develops in the early postoperative period in LT patients.

Some researchers have proposed that immunosuppressive therapy reduces the leukocyte count and suppresses the inflammatory response leading to a delayed diagnosis of AAp. $[7,8,14]$ The opponents of this hypothesis state that there is, in fact, no difference concerning leukocyte count between transplanted and non-transplanted patients with AAp. Sheppard and colleagues ${ }^{[6]}$ have stated that leukocytosis was observed in $73 \%$ of the LT patients with AAp, comparable to that in the non-transplanted patient population, and their hypothesis was supported by Savar et al. ${ }^{[4]}$ Our literature review showed that 28 of the 33 patients reported had data regarding leukocyte count, and $71.4 \%$ of these patients had leukocytosis (>10.000 cells $/ \mathrm{mm}^{3}$ ). In our case-control study, leukocytosis was observed in $30 \%$ of the LT patients in contrast to $76.9 \%$ of the non-transplant patients during the study period. The results of the study by Fonseca-Neto et al. ${ }^{[8]}$ are consistent with the findings obtained in our study. All in all, our results and the results of previous studies regarding this subject are contradictory. However, in our experience of over 2500 cases of LT, leukocyte levels in the post-transplant period are lower than the normal range observed in the general population as a result of immunosuppressive therapy.

The diagnosis of AAp in $L T$ patients requires evaluation of anamnesis, physical examination findings, laboratory values, and imaging studies. The differential diagnosis in LT patients with AAp should include intraabdominal infections, gastrointestinal perforations, biliary fistula, graft-related complications, rejection, and vascular thrombosis. ${ }^{[8,9,15]}$ As previously discussed, the leukocyte count and inflammatory response are reduced in immunosuppressed individuals. On the contrary, some studies state that inflammatory markers, such as RDW and CRP level, are elevated significantly in LT patients in contrast to non-transplant patients. However, when analyzed in detail, these parameters were found to be especially increased in complicated cases. ${ }^{[1]}$ Therefore, although statistically not significant, a higher perforation rate in the LT patients may explain the elevated CRP and RDW levels. Further, even though ultrasonography is a very effective diagnostic tool when performed by experienced personnel, abdominal computerized tomography is both effective in diagnosing complications related to the transplanted graft and also has higher sensitivity ( $91 \%$ vs. $78 \%$ ) and specificity ( $90 \%$ vs. $83 \%$ ) when compared to ultrasonography. ${ }^{[6,8]}$ Radiological studies are especially useful in post-transplant patients in whom leukocytosis is not observed. ${ }^{[9,15]}$

The majority of researchers have found no difference concerning the etiopathogenetic factors of AAp between transplant and non-transplant patients. ${ }^{[8,9,15]}$ However, there are 


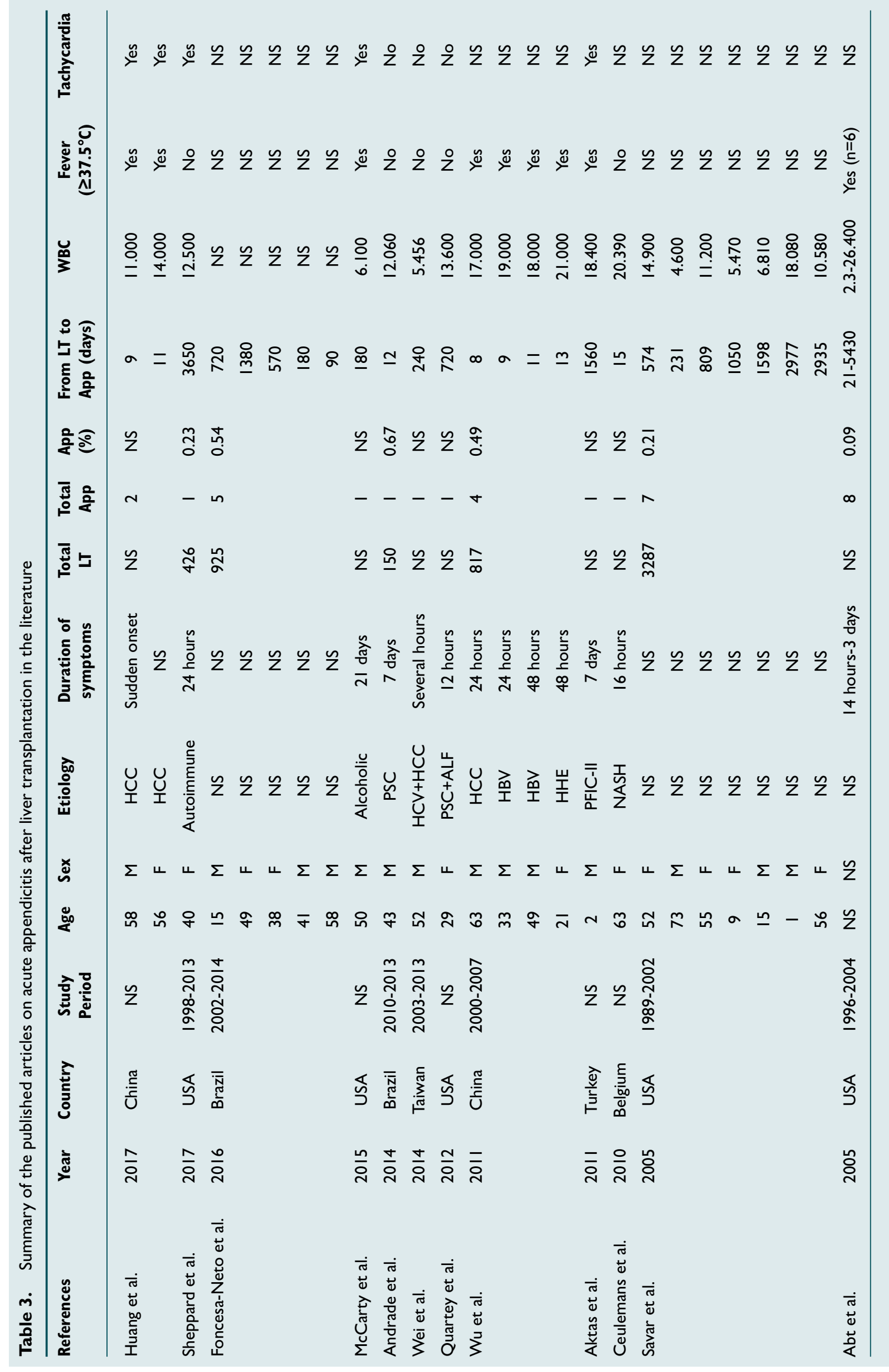




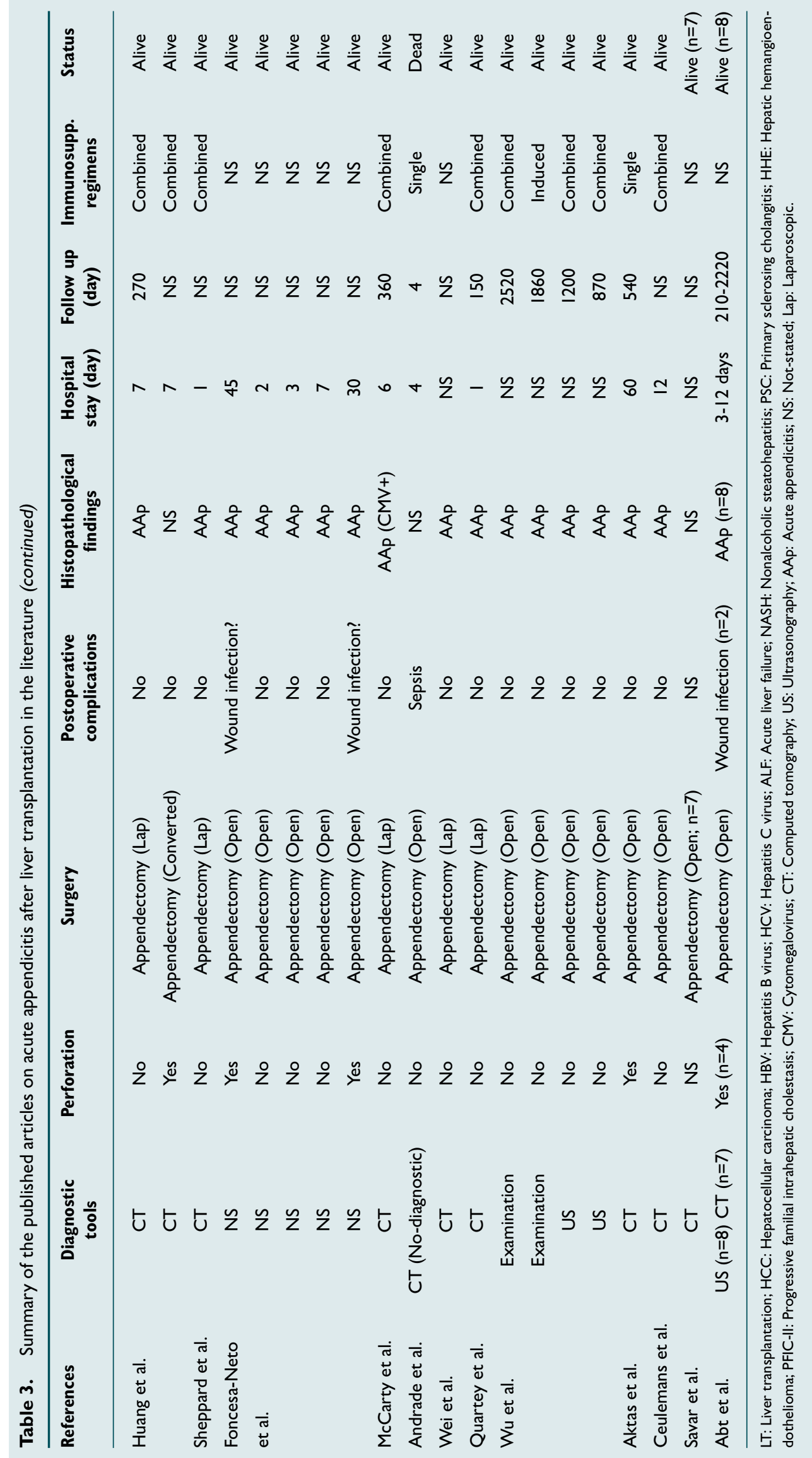


some opponents of this opinion. ${ }^{[6]}$ In fact, luminal obstruction and bacterial overgrowth are the two triggering factors in the development of clinical AAp. ${ }^{[8]}$ Our literature review revealed that only one LT patient had acute appendicitis due to CMV infection. ${ }^{[13]}$ Further, CMV-associated AAp is more common after kidney and bone marrow transplantation.

The gold standard therapeutic option for AAp is open or laparoscopic appendectomy. The timing of appendectomy depends on the development of complications (pylephlebitis, periappendicular abscess, and plastron) at the time of diagnosis. The basic principles of management for AAp in LT patients are the same as those for non-transplant patients. Our literature review showed that 27 transplanted patients had received open appendectomy, whereas five transplanted patients underwent laparoscopic appendectomy. ${ }^{[2,6,7,13,14]}$ In the remaining patient, a perforation was noticed during laparoscopic exploration and the operation was converted to open surgery. ${ }^{[3]}$ Although laparoscopic surgery is recommended in the early postoperative period, laparoscopic appendectomy may also be performed many years after the transplant surgery. ${ }^{[2,6,7,13,14]}$ The first trocar should always be placed under direct vision during laparoscopic appendectomy. In the open approach, if the diagnosis is confirmed in the preoperative period, a McBurney incision is preferred. Conversely, in cases with uncertain diagnoses, the old incision or midline incision should be used for the exploration of the abdomen. ${ }^{[15]}$ In the present case-control study, 12 LT patients underwent operation through the McBurney incision, and one patient received a paramedian incision for an appendectomy.

The most dreaded complications of appendicitis in transplant patients are perforation and intraabdominal sepsis. The rate for perforation in the non-transplant population ranges between $4-41.5 \%$, whereas it was reported to be $0-50 \%$ in LT patients. ${ }^{[8,11,18]}$ Abt et al. ${ }^{[1]}$ showed that in LT patients in whom the diagnosis was delayed or the admission was delayed by three days, the perforation rate was $75 \%$. This is supported by many other researchers. ${ }^{[2,9]}$ Our literature review showed that among the 26 patients with documented operative parameters, the perforation rate was $30.7 \%$, and no mortality case was noted. ${ }^{[3,7,8,11]}$ In previous literature, during the 4-2220 days of follow up, only one case of mortality related to AAp was observed. ${ }^{[9]}$ In the present study, $30.8 \%$ of the 13 LT patients developed perforation and none of the patients died. In our opinion, the main causes of perforation were the non-specific symptoms observed in the patients enrolled and late admission to the emergency department. Conversely, a high negative appendectomy rate in our institution may be attributable to our decision to operate in LT patients suspected to have AAp to avoid any complications.

In conclusion, to our knowledge, this study is the first study to compare AAp in LT patients to that in the normal population. WBC and neutrophil counts that are biomarkers of inflammation were lower in LT patients; however, the CRP level and RDW, markers of severe appendicitis, were higher in the LT patients. Although AAp has been known to be more frequent in the early post-transplant period, we showed that it may occur at any time following LT. Further, the rates of perforation and negative appendectomy were higher in LT patients than in the normal population, although this difference was not statistically significant. We believe that our results are relevant as, to our knowledge, this is the first and largest study on this subject concerning design and the number of cases reported. In addition, since AAp after LT is a very rare clinical entity, the multicentric study should be designed to comprehensively evaluate AAp in transplanted patients.

Ethics Committee Approval: Approved by the local ethics committee.

Peer-review: Internally peer-reviewed.

Authorship Contributions: Concept: S.A., A.T.; Design: S.A., K.B.S.; Materials: K.B.S., C.K., A.T.; Data: K.B.S., C.K., A.T.; Analysis: S.A.; Literature search: S.A., C.K., A.T.; Writing: S.A.; Critical revision: S.A., S.Y.

Conflict of Interest: None declared.

Financial Disclosure: The authors declared that this study has received no financial support.

\section{REFERENCES}

1. Akbulut S, Koc C, Kocaaslan H, Gonultas F, Samdanci E, Yologlu S, et al. Comparison of clinical and histopathological features of patients who underwent incidental or emergency appendectomy. World J Gastrointest Surg 2019;11:19-26. [CrossRef]

2. Quartey B, Dunne J, Cryer C. Acute appendicitis post liver transplant: a case report and literature review. Exp Clin Transplant 2012;10:183-5.

3. Aktas S, Sevmis S, Karakayali H, Ozcay F, Coskun M, Bilezikci B, et al. Acute appendicitis after diaphragmatic hernia after pediatric liver transplant. Exp Clin Transplant 2011;9:63-7.

4. Savar A, Hiatt JR, Busuttil RW. Acute appendicitis after solid organ transplantation. Clin Transplant 2006;20:78-80. [CrossRef]

5. de'Angelis N, Esposito F, Memeo R, Lizzi V, Martìnez-Pérez A, Landi F, et al. Emergency abdominal surgery after solid organ transplantation: a systematic review. World J Emerg Surg 2016;11:43. [CrossRef]

6. Sheppard SE, Marecki HL, Psoinos CM, Movahedi B, Furman MJ, Bozorgzadeh A, et al. Acute Appendicitis after Liver Transplantation: A Case Report and Review of the Literature. Int J Organ Transplant Med 2017;8:208-12.

7. Huang JF, Ma JF, Gong Y, Yu LL, Cui CX, Yang LX, et al. Acute Appendicitis in the Early Stage after Orthotopic Liver Transplantation. Chin Med J (Engl) 2017;130:1253-4. [CrossRef]

8. Fonseca-Neto OC, Lima HC, Melo PS, Melo PS, Lemos R, Leitão L, et al. Acute apendicitis in liver transplant recipients. Arq Bras Cir Dig 2016;29:30-2. [CrossRef]

9. Andrade RO, Pires RS, Silva RE, Mello FPT, Sousa CCT, Basto ST, et al. Acute Appendicitis after Liver Transplant: A Case Report and Review of the Literature. Open J Organ Transplant Surg 2014;4:29-32. [CrossRef]

10. Ferris M, Quan S, Kaplan BS, Molodecky N, Ball CG, Chernoff GW, et al. The Global Incidence of Appendicitis: A Systematic Review of Population-based Studies. Ann Surg 2017;266:237-41. [CrossRef] 
11. Abt PL, Abdullah I, Korenda K, Frank A, Peterman H, Stephenson GR, et al. Appendicitis among liver transplant recipients. Liver Transpl 2005;11:1282-4. [CrossRef]

12. Ince V, Barut B, Ozdemir F, Ersan V, Kutluturk K, Gonultas F, et al. The management of acute appendicitis in liver transplant patients: How effective is the Alvarado score? North Clin Istanb 2017;4:262-6. [CrossRef]

13. McCarty TP, Lee RA, Herfel BM, Pappas PG. Cytomegalovirus appendicitis in solid organ transplant patients, two cases and a review. J Clin Virol 2015;66:48-50. [CrossRef]

14. Wei CK, Chang CM, Lee CH, Chen JH, Yin WY. Acute appendicitis in organ transplantation patients: a report of two cases and a literature review. Ann Transplant 2014;19:248-52. [CrossRef]
15. Wu L, Zhang J, Guo Z, Tai Q, He X, Ju W, et al. Diagnosis and treatment of acute appendicitis after orthotopic liver transplant in adults. Exp Clin Transplant 2011;9:113-7.

16. Ceulemans P, Wybaillie E, Monbaliu D, Aerts R, Pirenne J. Acute appendicitis after liver transplantation: a case report and review of the literature. Acta Chir Belg 2010;110:335-8. [CrossRef]

17. Akturk OM, Cakir M, Yildirim D, Akinci M. C-reactive protein and red cell distribution width as indicators of complications in patients with acute appendicitis. Arch Clin Exp Med 2019;4:76-80. [CrossRef]

18. Balogun OS, Osinowo A, Afolayan M, Olajide T, Lawal A, Adesanya A. Acute perforated appendicitis in adults: Management and complications in Lagos, Nigeria. Ann Afr Med 2019;18:36-41. [CrossRef]

\section{ORIJINAL ÇALIŞMA - ÖZET}

\section{Akut apandisit ön tanısı ile apendektomi yapılan karaciğer transplantlı ve transplant dışı hastaların karşılaştırılması: Olgu kontrol çalışması \\ Dr. Kemal Barış Sarıcı, Dr. Sami Akbulut, Dr. Cemalettin Koç, Dr. Adem Tuncer, Dr. Sezai Yılmaz}

İönü Üniversitesi Tıp Fakültesi, Karaciğer Nakli Enstitüsü ve Genel Cerrahi Anabilim Dalı, Malatya

AMAÇ: Bu çalımanın amacı akut apandisit ön tanısıyla apendektomi olmuş karaciğer transplantlı ve transplant dışı hastaları karşılaştırmaktır. GEREÇ VE YÖNTEM: Posttransplant dönemde akut apandisit ön tanısıyla apendektomi yapılan I 3 karaciğer transplantlı hasta (transplant grubu) ile aynı dönemde apendektomi olmuş transplant dışı 52 hasta (non-transpalnt grubu) demografik ve klinikopatolojik özellikler yönünden karşılaştırıldı. Transplant ve non-transplant gruplar I:4 rastgele eşleştirme yöntemi kullanılarak oluşturuldu. Devamlı değişkenlerin karşılaştırılmasında MannWhitney U-testi kullanılırken kategorik değişkenlerin karşılaştırılmasında Fisher kesin testi kullanıldı. P değeri <0.05 istatistiksel anlamlılı sınırı olarak kabul edildi.

BULGULAR: Bu çalışmaya yaşları I ile 84 yıl arasında değişen toplam 65 hasta alındı. Non-transplant grubundaki 52 hastanın (32 erkek ve 20 kadın) I7 ile 84 yıl arasında değişirken transplant grubundaki 13 hastanın ( 9 erkek ve 4 kadın) yaşları I ile 64 yıl arasında değişmekteydi. Gruplar arasında WBC $(p=0.002)$, nötrofil $(p=0.002)$, lenfosit $(p=0.032)$, trombosit $(p=0.032), \operatorname{RDW}(p=0.001), C R P(p=0.009), P N R(p=0.042), W N R(p=0.03)$ ve apendiks uzunluğu $(p<0.00$ I) açısından istatistiksel olarak anlamlı farklılıklar saptandı. Negatif apendektomi oranı transplant grubunda nisbeten daha yüksek olmakla birlikte bu farklılık istatistiksel olarak anlamlı değildi (\%30.8 ve \%2 I.2; p=0.477). Perfore apandisit transplant grubunda çok daha sık görülmekle birlikte bu farklılık istatistiksel olarak anlamlı değildi (\%30.8 ve \%9.6; $p=0.070)$.

TARTIŞMA: WBC ve nötrofil LT grubunda daha düşüktü; CRP ve RDW LT grubunda daha yüksekti. Perforasyon ve negatif apendektomi oranları LT grubunda daha yüksekti, ancak bu fark istatistiksel olarak anlamlı bulunmamıştır.

Anahtar sözcükler: Akut apandisit; karaciğer alıcıları; karaciğer nakli; negatif apendektomi; perfore apandisit.

Ulus Travma Acil Cerrahi Derg 2020;26(5):705-712 doi: 10.14744/tjtes.2020.52368 